\title{
ВЕЛИКИ РАТ У ДНЕВНИЧКИМ ЗАПИСИМА АЛЕКСАНДРА Б. ЦВЕТКОВИЋА (1916-1919)
}

\begin{abstract}
У реферату је анализиран непознати рукопис ратног дневника Александра Б. Цветковића (1891-1962), земљорадника из сувопланинског села Шпај у белопаланачкој општини, који је у Првом свјетском рату био првопозивац, наредник 4. чете 3. батаљона Трећег (пиротског) пешадијског пука Моравске дивизије. Дневник је под називом Бележник из Великог рата (1916-1919) објављен 2018. године заслугом Јована Младеновића и Немање Нешића, а представља један од најнепосреднијих приказа рата који је потекао из редова српских војника. У нашој интерпретацији је указано на субјективни доживљај рата, али и на документарну аутентичност свједочења, те на језичке и стилске особине дневничких записа.
\end{abstract}

Кључне ријечи: српска књижевност, Велики рат, дневник, записи, документарност, прича

1.0.Крупан историјски догађај, какав је био Велики рат (1914-1918), оставио је бројна књижевна документарно-умјетничка свједочења, дневничке и мемоарске записе, као и белетристичка остварења, попут романа, приповједака и драма, лирских пјесама и спјевова. За српски народ тај историјски догађај био је посебно драматичан због тога што је српска војска и српска влада била принуђена да се повуче преко Албаније у јесен 1915. године пред најездом аустријске и бугарске војске, као и због тога што је српска државна територија била у наредним годинама под окупацијом (1915-1918). Посебну историјску вриједност имала је велика ратна улога српске војску у пробоју Солунског фронта у септембру 1918. године. Све то је оставило крупан књижевни траг, а о ратним годинама су подједнако писали знани и незнани учесници и непосредни свједоци рата, а међу њима и сасвим познати књижевници (Бранислав Нушић, Станислав Краков), као и сасвим непознати појединци који нису ни помишљали да се баве писањем. Овом приликом са посебним пијететом издвајамо наслове Нушићеве мемоарске књиге Деветсто петнаеста - трагедија једног народа, као и мемоарске књиге Станислава Кракова Живот човека на Балкану. Међу романескним

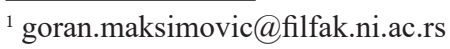


текстовима незаобилазни су Дневник о Чарнојевићу Милоша Црњанског, Дан шести Растка Петровића, Црвене магле Драгише Васића, сви написани у изразитом експресионистичко-модернистичком поетском кључу. Насупрот њима, налазе се романи Деветсточетрнаеста, Под крстом и Капија слободе, Стевана Јаковљевића, познатији под називом Српска трилогија, у којима је дата херојско-реалистичка слика ратног страдања и патње српског народа.

Међутим, овога пута наша истраживачка пажња усмјерена је према ратним рукописима оних непознатих појединаца, непосредних учесника и свједока ратне катаклизме, а међу њима посебно издвајамо ратни дневник Александра Б. Цветковића (1891-1962), земљорадника из сувопланинског села Шпај у белопаланачкој општини, који је у Првом свјетском рату био првопозивац, наредник 4. чете 3. батаљона Трећег (пиротског) пешадијског пука Моравске дивизије. Дневник је под називом Бележник из Великог pama (1916-1919) објављен 2018. године заслугом Јована Младеновића и Немање Нешића, а представља један од најнепосреднијих приказа рата који је потекао из редова српских војника. Приређивачи су поштовали основну концепцију рукописа Бележника и приликом штампања сачували су „пет делова", а све то означили и посебним графичким ознакама, као што су бројеви страна, угласте заграде и сл. При томе су у подножним напоменама дали исцрпне и веома добре коментаре појединих дијелова дневничког рукописа и тако су читаоце увели у историјски контекст и припремили за што потпуније разумијевање текста. Најчешће су то коментари који указују на историјске и политичке околности, организацију српске војске, командни кадар, односе међу великим свјетским силама које су заједно ратовале, као и догађаје који су пратили кретања на Солунском фронту, али су присутна објашњења и бројних топографских одредница, географских локалитета, дијалекатске лексике и сл.

У нашој интерпретацији учинило нам се да се ради о једном од најаутентичнијих субјективних доживљаја рата, који је истовремено значајно очувао и документарну непосредност свједочења, као и језичке и стилске особине дневничких записа. ${ }^{2}$ Ради се о спонтаном виђењу и слици рата, коју записивач није намјеравао да објелодањује било коме, а најмање је планирао да све то објави као књигу која би постала доступна најширој јавности, тако

\footnotetext{
${ }^{2}$ Сличан тип ратних записа, пронашли смо и код војника 3. митраљеског одељења 14. Пешадијског пука Тимочке дивизије, Стојана Ј. Јевтића (1893-1981), из села Балановац код Књажевца. Објављени су из рукописа 2018. године у издању Завичајног музеја из Књажевца

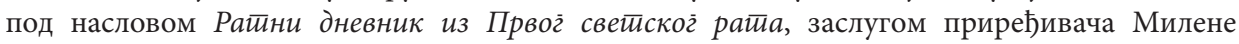
Милошевић Мицић. Јевтићев дневник обухватио је раздобље од краја септембра 1915. до почетка фебруара 1919. године. У овом огледу наша аналитичка пажња биће усмјерена искључиво према ратном дневнику Александра Б. Цветковића, али ћемо у некој од наредних расправа свакако усмјерити интерпретацију и наведене дневничке записе Стојана Ј. Јевтића, јер то они заслужују у сваком погледу.
} 
да и није било говото никакве значајније самоцензуре или стилизовања и преправљања једном сачињеног рукописа.

2.0. Дневнички записи Александра Б. Цветковића Бележник из Великог рата (1916-1919), обухватају временски распон од 4. септембра 1916. године до 24. марта 1919. године. (Наглашавамо да су сви датуми у дневнику навођени по старом календару). Карактерише их изразита сажетост исказа, одсуство сувишних коментара, белопаланачки дијалекатски говор, као и прецизност у навођењу ратних локалитета, као и свакодневних догађаја на фронту. „По таксатином начину излагања и хладном извештајном стилу, сличан је официрским операцијским дневницима" (Младеновић/Нешић, 2018: 7). Почетни дневнички записи усмјерени су на приказивање атмосфере поводом покретања војничких акција за ослобођење Битоља у септембру и октобру 1916. године. Описано је пребацивање Цветковићеве треће чете ка непријатељским рововима у којима се налазила бугарска војска. Пошто су били на непосредном растојању од 30 до 40 метара, између сукобљених војника је непрестано размјењивана ватра са сталним рањавањима и погибијама војника. Непрестано су се смјењивали напади и контранапади, због чега су били принуђени да се враћају на почетне положаје. Цветковић укратко саопштава да је 16. октобра био „лако рањен“ у лијеви кук од шрапнела непријатељске бомбе, али да се послије превијања одмах вратио на фронт. Двије седмице иза тога описује напад српске војске на непријатељску линију када је са четом заузео непријатељски ров, а њему и војнику Новици Мољевићу су се предала двадесет два немачка војника. Интересантно је да тај несумњиво херојски војнички подвиг, Цветковић описује смирено и без велике егзалтације, као нешто сасвим уобичајено, свакодневно и нормално у животу војника на фронту. Запис завршава констатацијом да су заробљене војнике послали назад, тј. у своју ратну позадину, те да су након тог догађаја ту остали цијелу ноћ и да су одржали освојени положај.

У борбама вођеним 8. новембра ујутро Цветковић казује да је приликом једног раног контранапада непријатеља поново рањен бомбом и то овога пута „у десни образ и браду” (Цветковић, 2018: 25). Тада је рана била много озбиљнија тако да је 24 дана провео у енглеској болници у Солуну на опоравку. Одмах по изласку из болнице, а прије повратка у јединицу на фронт, Цветковића су одвезли у „српски депо” на аеродрому Седес код Солуна, гдје је преспавао, а сутрадан 6. децембра (по старом календару), уочи Светог Николе, отишао је у мјесну цркву на литургију, а затим описује како је скромно са војницима прославио своју „славицу” Никољдан.

Цветковићев дневник у 1917. години представља наставак сажетих ратних описа на фронту. Поред свакодневног ратног искушења, описани су и позадински догађаји. Сазнајемо о томе како војници примају плату у 
францима, о томе како је као наредник бринуо о сљедовањима хране, о чистој војничкој униформи, вешу и кошуљама, а посебно је бринуо о муницији и наоружању. Цветковић описује и свакодневно дјеловање непријатељских аероплана чије су бомбе наносиле губитке српској војсци и бројна рањавања. Цветковић казује како је 26. августа доживио саморањавање приликом испаљивања сигналних ракета. Тада је озлиједио „леву страну” лица „до самог ока". Одмах је превијен, извађено му је парче шрапнела и послат је на мазги, уз пратњу два војника „у пуковску амбуланту” (Цветковић, 2018: 46). У истоветним данима ратне свакодневнице 1917. године, Цветковић са посебним задовољством описује како је обиљежио своје „крсно име” Светог Николу, када су га посјетили бројни војници и поднаредници, као и надређени официри, а међу њима и командант батаљона. Цветковић описује да је крајем децембра морао да пише рапорт за редова Миладина Ђорђевића који је добио дозволу за одсуствовање па се није на вријеме вратио у јединицу. Иза тога је морао поново да тражи љекарску помоћ и провео је четири дана поштеде због појаве кожног обољења, највјероватније шуге и свраба.

У Цветковићевим дневничким записима из 1918. године јасно се уочава појачавање војничких дејстава на фронту, што је била очигледна припрема за одлучујући пробој линије фронта. У дневнику се дискретно појављују и информације о појавама дезертерства, о бугарској ратној пропаганди која је уносила дефетизам међу српске војнике, а која је проистекла из незадовољства због вишегодишњег одсуства од куће. Између осталог, читав проблем је ескалирао када је дошло до изјаве у једној чети трећег батаљона шумадијског пука да желе да напусте фронт, да је све изгубљено и да се не вриједи борити. Описане су и појаве употребе хемијског оружја у дјеловању непријатељске војске по српским положајима, иако је то оружје било забрањено Хашком конвенцијом. Цветковић описује и неке свакодневне догађаје, попут свађе коју је имао са поднаредником Ђорђем Плавшићем, о чему нас упознаје у неколико записа насталих између 17. и 22. јануара 1918. године. Радило се о сасвим непотребном неспоразуму због новца који су сакупљали за куповину неких ствари у Солуну. Ишли су због тога и на рапорт код командатна батаљона, а напокон су се измирили 22. јануара: „Ујутру дошао је поднаредник Плавшић у мојој земуници те смо се измирили и дао ми часну реч да више неће дозволити да се долази до таке непријатности“ (Цветковић, 2018: 63). У дневничким записима су присутни и поједини мирнодопски догађаји, проистекли из војничког одсуства. Цветковић описује како је 24. априла 1918. године отпутовао у Солун новоизграђеном пругом од Битоља до Солуна, а да се у чету вратио петнаестак дана касније.

У запису од 16. маја 2018. године, Цветковић наглашава да су посебно вјежбали намјештање маски за одбрану од хемијских отрова: „Нов пропис је: намешћем за 40 секунда а стар пропис за 2 минута; затим смо наместили маске и држали 26 минута“ (Цветковић, 2018: 78). Очигледно је да је то ново 
увођење стандарда за постављање маски за заштиту војника од дејства хемијских отрова на ратишту био знак скоре најаве великог пробоја Солунског фронта. У запису од 18. маја 2018. године, Цветковић наглашава да се ,јавио за лекарску помоћ“ (Цветковић, 2018: 79), а затим у сваком дневничком запису до 31. маја напомиње да је ишао на прегледе код љекара у пуковској амбуланти, али није навео шта се то десило и због којих тегоба је ишао код љекара. Иза тога је у запису од 31. маја написао да је био смјештен у пуковској амбуланти све до 26. јуна, очигледно је био на лијечењу, али је напоменуо да разлози нису предстваљали „ништа значајније” (Цветковић, 2018: 80). У запису од 1. јула 2018. године, док је био размјештен у батаљонској резерви, Цветковић записује да су тог дана сви „примили шампањ, по четири војника на флашу”, поводом обиљежавања „празника фрацуске Бастиље” (Цветковић, 2018: 81). Подсјећамо да се према данашењем календару тај француски државни празник обиљежава 14. јула.

Интензивнија гибања на фронту осјетила су се након уласка Грчке у рат на страни Антанте, 2. јула 1918. године, а завршне ратне припреме пробоја Солунска фронта започете су након именовања француског генерала Франша д’ Епереа за команданта савезничких снага. Истовремено, у српској војсци војвода Живојин Мишић је именован за начелника генералштаба, а генерал Петар Бојовић за командата Прве армије. Иако то у дневничким записима није непосредно наведено, јер војска а међу њима и писац дневника, наредник Цветковић, нису имали поуздана сазнања о томе, али познато је из историјских извора да је тог љета било великих неслагања између команде савезничких снага и команде српске војске. Највећи проблем био је у томе што је Српска врховна команда жељела да се што прије крене у пробој фронта са потпуним увјерењем да је српска војска посједовала капацитет да изнесе највећи терет тог војничког подухвата. Са друге стране, Французи су били уз Српску врховну команду, али су одлуку одуговлачили Енглези и Италијани.

Цветковић у дневнику записује да је његова јединица прошла кроз медицински третман дезинфекције, а затим је кренула на Кајмакчалан 12. августа 1918. године, гдје су се улогорили и нестрпљиво ишчекивали почетак пробоја. Када је пробој напокон отпочео, 15. септембра 1918. године, догађаји на ратишту су се одвијали таквом брзином да је Цветковић стизао само укратко да извјештава како напредује његова чета и до којих градова и села су стигли. Пробили су Кајмакчалан, продирали су кроз Овчепољску равницу, а већ послије неколико дана су били у Куманову. Када су били у Прешеву, 20. септембра, сустигла их је вијест о капитулацији Бугарске, а већ послије пет дана пролазили су јужноморавском долином кроз Џеп и село Стајковац. Два дана иза тога стигли су у Заплање и село Доњи Барбеш изнад Ниша.

Цветковић на даљим страницама дневника биљежи како је његова јединица у ратном надирању отишла све до Малог Могрог Лука, надомак 
Београда, а затим се вратила на правац од Ковина према Вршцу и да су у том граду били стационирани од средине новембра 1918. до друге половине марта 1919. године. Цветковић окончава вођење дневника 24. марта 1919. године, када је због болести био стациониран у Вршачкој болници, а од 23. априла до 26. маја провео је мјесец дана код куће на одсуству. Био је то повратак у родни дом послије готово четири ратне године одсуствовања.

Важно је истаћи да у овом дневничком сегменту, Цветковић наглашава да је у свим мјестима гдје су долазили било изузетно свечано и узвишено расположење. Народ их је дочекивао са великим одушевљењем као дуго ишчекиване ослободиоце. Из дневничког записа од 30. октобра 1918. године, закључујемо да је то нарочито било изражено у Ковину, гдје их је народ дочекао у правој паради „са фијакерима и јахаћим коњима”, а увече су им доносили „пиће и јестиво” (Цветковић, 2018: 103), у мјесну школу гдје су били на становању.

У неким другим дијеловима дневничких записа, Цветковић свједочи и неке сасвим необичне датуме и догађаје. На примјер, у запису од 15. јануара 1919. године, који је настао у Вршцу, сазнајемо да је тог дана донијета државна одлука о изједначавању старог и новог календара: „Наређено је да се данашњи дан има обележити као 28. по новом календару” (Цветковић, 2018: 109). У овом запису иначе у потпуности долази до изражаја Цветковићева битна дневничка карактеристика да не коментарише или на било који други начин исказује свој став подршке или противљења неким битним одлукама које су долазиле из надређене команде или, као у овом примјеру, од државне администрације.

2.1.Овдје морамо напоменути још једну важну чињеницу из Цветковићевог дневника, а која се не односи на непосредан приказ Великог рата. На почетку Другог светског рата Цветковић оставља неколико записа о томе како је био мобилисан 28. марта 1941. године, те како је убрзо иза тога, започео рат 6. априла. Из дневничког записа сазнајемо да је већ 8. априла Цветковић био рањен „на три места у главу” (Цветковић, 2018: 113) од шрапнела једне њемачке авионске бомбе док је био у рову испред белопаланачке школе. Због тога је транспортован у Нишку болницу, тако да је ту 9. априла дочекао долазак Нијемаца у Ниш. Отпуштен је из болнице 23. априла, али је одмах отјеран у логор Црвени Крст, а већ сутрадан је возом транспортован са групом заробљеника у Софију. Након четири дана је ослобођен и вратио се кући у село Шпај код Беле Паланке 30. априла 1941. године. Након тога у дневнику постоји један значајан прекид записивања догађаја, све до 6. новембра 1942. године. Можда су ти дијелови рукописа касније изгубљени. У том посљедњем сачуваном запису од 6. новембра 1942. године, Цветковић свједочи да је пошао из Беле Паланке у Борски рудник, али да га је срео председник Општине Шпајске, Милутин Крстић, вратио га кући уз 
обавјештење да је ослобођен. Ово је јасан знак да је у вријеме бугарске окупације југоисточне Србије у Другом свјетском рату, Цветковић у интервалу од маја 1941. до новебра 1942. године највјероватније одвођен на принудни рад у Борски рудник, а да му је тог 6. новембра 1942. године јављено да је ослобођен од те радне обавезе.

3.0.Дневник наредника Александра Б. Цветковића написан је непретенциозно, као једна врста његовог подофицирског подсјетника о свакодневним обавезама и задацима, али нам је саопштио једну потпуно аутентичну, непосредну слику Великог рата, као и исцрпљујућих борби на Солунском фронту, онако како су стварно изгледале из перспективе војника који су мјесецима и годинама рањавани и гинули у борбама, а при томе непрестано жудили за повратком у домовину. Најснажнија порука коју потомцима оставља Александар Б. Цветковић говори о томе да је слобода највећа драгоцјеност сваког појединца и читавих народа, а да је тек у рату и тек онда када се борима за њу та вриједност препозната као нешто непроцјењиво. Дневник показује и како је обичан човјек, када то мора, невјероватно сналажљиво и издрљиво биће, те како и у најтежим околностима има снаге да створи привид нормалног мирнодопског живота. Нарочито је то упечатљиво у описима скромних, али веома важних „крсних слава”, у добијању поште и писама од куће, у описима одлазака на допусте и провођења слободних дана у Солуну, у приказу малих људских радости и ведрих емоција, али и патње која је произлазила из свакодневних страдања на фронту и дугогодишње жудње за родним домом и завичајем.

\section{Литература}

Цветковић (2018). Александра Б. Цветковић, Бележник из Великог рата, Народни музеј, Ниш, 117 стр.

Младеновић/Нешић (2018). Јован Младеновић/Немања Нешић, предг. у књизи: Александар Б. Цветковић, Бележник из Великог рата, Народни музеј, Ниш, c. 7-11. 
Goran M. Maksimović

\section{FIRST WORLD WAR IN DIARY NOTES BY ALEKSANDAR B. CVETKOVIĆ (1916-1919)}

\section{Summary}

The paper analyzed the unknown manuscript of the war diary by Aleksandar B. Cvetković (1891-1962), a farmer from the Šopaj village in the Belopalan municipality, who was the first warlord in the First World War, the commander of the 4th Battalion of the 3rd Detachment of the Third (Pirot) Infantry Regiment of the Moravian Division. The diary was called The Great War Warner (1916-1919) published in 2018 by the merit of Jovan Mladenović and Nemanja Nešić, and is one of the most direct sources of the war picture that came from the ranks of Serbian soldiers. In our interpretation we pointed out the subjective experience of war, as well as the documentary authenticity of the testimony, and the linguistic and stylistic features of the diaries.

Key words: Serbian literature, The Great War, diary, records, documentary, story. 